Ivana Bahun ${ }^{1}$

Psychiatric hospital "Sveti Ivan", Zagreb

\section{Aleksandra Huić}

\section{Department of} Psychology, Faculty of Humanities and Social Sciences, University of Zagreb

' Author's address:

bahunivana@gmail.com

Primljeno: 10. 10. 2016.

Primljena korekcija:

07. 11. 2016.

Prihvaćeno za štampu:

14. 11. 2016.

\section{INTIMATE RELATIONSHIPS IN CONTEXT: STRESS SPILLOVER, RELATIONSHIP EFFICACY, AND RELATIONSHIP SATISFACTION}

Recently, research has shown that stress experienced outside the relationship is negatively associated with relationship outcomes, such as relationship satisfaction. However, the exact mechanisms through which this phenomenon, also known as stress spillover, effects relationships are not completely clarified. Also, most of the studies utilized married couples, and less is known about stress spillover in dating relationships. The aim of this study was to investigate relations between external stress, relationship efficacy, and relationship satisfaction in dating relationships. A total number of 390 men and women, aged from 18 to 35 participated in the study. Our participants were dating for at least six months, but did not live with their partners. The results showed that experiencing greater levels of external stress was associated with lower relationship satisfaction. Both experienced external sources of stress and perceived distress significantly contributed to explaining relationship satisfaction. The results indicated that relationship efficacy mediateed the relationship between experienced and perceived stress and relationship satisfaction. Higher levels of experienced and perceived stress were associated with lower perception of relationship efficacy, which was related to lower relationship satisfaction. Our findings point to the importance of self-regulation processes for relationships outcomes in dating relationships in emerging adulthood. It seems that lower relationship efficacy partly explains the detrimental effects of external stress spillover on relationships.

Keywords: partner relationships, context, stress spillover, relationship efficacy, relationship satisfaction 
Nowadays, , in their quest to fully understand intimate relationships, relationship researchers are turning to the importance of external context of those relationships. Stress experienced outside the relationship (e.g. at work, daily hassles, etc.) represents an important contextual factor. This stress spills over into the relationship and puts a strain on it, a phenomenon called stress spillover (see Randall \& Bodenmann, 2009 for review). It hinders adaptive relationship processes and lowers our relationship satisfaction, as witnessed by declines in marital satisfaction after periods of greater outside stress (Neff \& Karney, 2009).

Various studies investigated mediators of the negative relationship between outside stress and relationship satisfaction, clarifying pathways by which this phenomenon occurs. They found external stress to be associated with negative mood (Repetti, Wang, \& Saxbe, 2009), social withdrawal (Repetti, 1989), more negative perceptions of relationships (Neff \& Karney, 2004), more negative communication between partners (Bodenmann, 1997), diminished capacities for regular relationship maintenance and deteriorated self-regulatory skills (Buck \& Neff, 2012). Also, it seems that believing in our ability to cope with stressful situations has an important role for stress spillover effects, both on an individual and dyadic level. In a longitudinal study Bodenmann and Cina (2006) showed that couples displaying poorer coping skills were more likely to be divorced or in less stable marriages after five years.

Our coping skills can stem from our feelings of self-efficacy (Bandura, 1982). Our beliefs in our own abilities to reach our goals and tackle life problems have been conceptualized as a personal resource, and their buffering effects against negative consequences of stress have been established (Jerusalem \& Schwarzer, 1992). In a similar vein, one could expect that perceived relationship efficacy, comprising of beliefs in our abilities to solve relationship problems (Fincham, Harold, \& Gano-Phillps, 2000), will have positive effects on relationship outcomes, and a buffering effect on stress in relationships. Indeed, higher levels of perceived relationship efficacy have been related both to more relationship satisfaction (Lopez, Morúa, \& Rice, 2007; Shurts \& Myers, 2012), and more constructive relationship problem solving skills (Neff \& Broady, 2011). Also, it plays a protective role for mental health outcomes of women in stressful, aggressive relationships (Sullivan, McPartland, Price, Cruza-Guet, \& Swan, 2013). Furthermore, self-efficacy beliefs make us persist in difficult tasks longer and make us try harder, because of which they are inextricably linked to self-regulation processes (Bandura, 1982). Based on the previously established importance of cognitive beliefs and self-regulatory processes, as mediators of the negative relationship between external stress and relationship satisfaction, and general buffering effects of self-efficacy against stress, one could posit that perceived relationship efficacy represents an important pathway by which stress spillover exerts its negative effects on relationship satisfaction. The main goal of our study was to examine this mediating role.

Stress spillover research has mostly been done on married couples. However, nowadays people opt to date for a significantly longer period of time before 
getting married, and they try out numerous dating relationships. These modern tendencies deserve more research attention, which should be given to contextual determinants of relationship satisfaction in dating relationships in emerging adulthood, which we attempted in this study. Similarly, Bowlin (2013) tried to replicate the above mentioned effects of stress spillover on students in dating relationships. She did manage to confirm the effect, although some of the results failed to reach statistical significance, possibly due to the fact that her research was focused solely on stress perceived in an academic environment, and by college students only, limitations we tried to address in this study.

According to the most influential theory of stress, our cognitive appraisal of a situation as overwhelming or threatening to our well-being is the most important factor that determines our subjective experience of stress (Lazarus \& Folkman, 2004). There are two kinds of cognitive appraisals, and outcomes of stressful experiences will depend on both. During primary cognitive appraisal, we evaluate the overall experience of stress, while during secondary cognitive appraisal, which is based on the level of control that we have over the situation, we evaluate our resources to deal with the situation efficiently. Different kinds of cognitive appraisals create the need to distinguish among these aspects. Measures of experienced stress provide information about the amount of stressful circumstances in a person's life. Therefore the response is a result of the primary cognitive appraisal, whereas the assessment of perceived stress, as a result of secondary cognitive appraisal, offers a subjective perspective that encompasses thoughts and feelings associated with those stressful situations.

In order to better understand stress spillover in dating relationships our aim was to investigate the relationships between experiences of external stress, levels of perceived stress, self-efficacy in intimate relationships and relationship satisfaction. We expected that more external stress and higher levels of perceived stress will be associated with lower relationship satisfaction. We also expected self-efficacy beliefs to significantly mediate this relationship. More experiences of external stress and higher levels of perceived stress will be related to lower relationship efficacy which in turn will be related to lower relationship satisfaction.

\section{Method}

\section{Participants and procedure}

A total number of 390 women (69\%) and men (31\%), aged 18 to $35(M=$ $23.42, S D=3.05$ ), participated in an on-line study (via social networks, group email addresses and internet portals). On average, participants were in their current relationship for 2.88 years $(S D=2.07)$, and the duration spanned from 6 months to 9 years. Participants did not live with their partner. College students made the majority of the sample (72\%). More than two thirds of participants 
(81.5\%) saw their partner every day or on weekends, and $19.5 \%$ of them reported that they sometimes did not see their partner for a week or longer. Approximately $81 \%$ of participants stated that their daily duties partially or fully overlapped with those of their partner's.

\section{Measures}

External Stress Sources Scale (adjusted according to Neff \& Broady, 2011). The scale consists of items referring to 9 categories that represent different life domains: partner relationship, family, friends, work/school, finances, everyday hassles (e.g. traffic), living conditions, health, and current political and social events. Participants were asked to assess the quality of their experiences within each of these domains in the last 6 months by evaluating the circumstances in each domain from 1 = extremely positive to $9=$ extremely stressful. In order to get data about stress experienced exclusively outside the relationship, we excluded the source "partner relationship" from the total score. Factor analysis resulted with one factor that explained a total of $36 \%$ of variance. Internal consistency was satisfactory $(\alpha=.76)$. Theoretical range spanned from 8 to 72 , with a higher score indicating more experienced stressful circumstances.

Perceived Stress Scale (Cohen, Karmack, \& Mermelstein, 1983). This scale consists of 14 items measuring how much the respondents see their life as unpredictable, uncontrollable and overloaded, and how stressful they appraise it. Questions refer to thoughts and feelings related to stress perceived in the past month, e.g. "In the last month, how often have you felt that you were unable to control the important things in your life?". Participants responded on a scale from $0=$ never to $4=$ very often. A higher score indicated higher levels of perceived stress. Theoretical range spanned from 0 to 56. Internal consistency was $\alpha=.63$.

Relationship Efficacy Measure (Fincham, Harold, \& Gano-Philips, 2000). Relationship Efficacy Measure presents respondents with 7 statements regarding their ability to successfully deal with disagreements and conflicts that arise between them and their partner, e.g. "When I put my mind to it I can resolve just about any disagreement that comes up between my partner and me." (1 = strongly disagree to 7 = strongly agree). The theoretical range spanned from 7 to 49 . A higher score meant a higher level of relationship efficacy. Reliability ( $\alpha=.87)$ was high.

Relationship Satisfaction was measured with one item that equals a global subjective assessment of satisfaction, with answers ranging from 1 = completely dissatisfied to 7 = completely satisfied. Although one-item measures could be problematic concerning the determination of metric characteristics, prior research showed very high correlations between a global measure and results obtained on more complex measures of relationship satisfaction, which justified the use of a more economic global assessment of relationship satisfaction (Tadinac et al., 2005). 


\section{Results}

Preliminary analyses showed that participants were mostly satisfied with their relationships. Also, they evaluated their relationship efficacy as pretty high. Levels of experienced external stress were moderate, while levels of perceived stress were slightly higher than the middle point of the scale (Table 1). There were no statistically significant differences between men and women on all examined variables.

Table 1

Correlations and descriptive statistics for study variables $(N=390)$

\begin{tabular}{lcccccc}
\hline & 1 & 2 & 3 & 4 & 5 & 6 \\
\hline (1) Common time & - & $.228^{* *}$ & -.088 & $-.174^{* *}$ & $.168^{* *}$ & $.239^{* *}$ \\
(2) Overlap of duties & & - & -.086 & -.053 & .088 & $.160^{* *}$ \\
(3) External stress sources & & & - & $.313^{* *}$ & $-.273^{* *}$ & $-.231^{* *}$ \\
(4) Perceived stress & & & & - & $-.393^{* *}$ & $-.238^{* *}$ \\
(5) Relationship efficacy & & & & & - & $.457^{* *}$ \\
(6) Relationship satisfaction & & & & & & - \\
\hline \multicolumn{1}{c}{$M$} & 1.69 & 1.91 & 32.76 & 32.26 & 31.15 & 5.99 \\
\multicolumn{1}{c}{$S D$} & 0.779 & 0.524 & 10.288 & 8.058 & 5.932 & 1.148 \\
\hline
\end{tabular}

${ }^{*} p<.05 .{ }^{* *} p<.01$.

Correlations between the variables are shown in Table 1. Higher levels of experienced external stress and higher perceived stress were associated with lower relationship satisfaction. Higher levels of relationship efficacy were associated with higher relationship satisfaction, while lower levels of relationship efficacy were associated with experienced and perceived stress. Out of different relationship-demographics, the amount of common leisure time and the extent of overlap between daily duties were significantly correlated with relationship satisfaction. The less time partners spent together, and the less their daily duties overlapped, their relationship satisfaction was lower. Therefore, we included these in our subsequent analyses as controls. Relationship duration was significantly correlated neither with relationship satisfaction nor with other studied variables ( $r$ ranged from -.03 to -.11, all n.s.), and therefore it was not included in further analyses.

To test the predictive role of experienced external stress, and perceived stress and relationship efficacy, we performed a hierarchical regression analysis with relationship satisfaction as a criterion variable (Table 2). 
Table 2

Results of hierarchical regression analysis with relationship satisfaction as criterion $(N=390)$

\begin{tabular}{lccc}
\hline Predictor & 1. step $(\beta)$ & 2. step $(\beta)$ & 3. step $(\beta)$ \\
\hline Overlap of duties & $.111^{*}$ & $.098^{*}$ & .084 \\
Common time & $.213^{* *}$ & $.176^{* *}$ & $.141^{* *}$ \\
External stress & & $-.159^{* *}$ & $-.097^{*}$ \\
Sources & & & \\
Perceived stress & & $-.153^{* *}$ & -.026 \\
Relationship efficacy & & & $.390^{* *}$ \\
\multicolumn{1}{c}{$\quad R^{2}$} & $.069^{* *}$ & $.131^{* *}$ & $.254^{* *}$ \\
\multicolumn{1}{c}{$\Delta R^{2}$} & $.069^{* *}$ & $.062^{* *}$ & $.123^{* *}$
\end{tabular}

Note. $\beta=$ standardized regression coefficient; $R^{2}=$ proportion of explained variance; $\Delta R^{2}=$ change in explained variance.

$* p<.05 . * * p<.01$.

We built our model by adding control variables (common leisure time and daily duties overlap) in the first step, then by adding our main predictors of interest (experiences of external stress and perceived stress) in the second step. In order to observe changes in our second step predictors, we added relationship efficacy in the third step. The first step explained $6.9 \%$ of criterion variance. In the second step, both experienced external stress and perceived stress were significant predictors which explained an additional $6.2 \%$ of variance. By adding the relationship efficacy in the third step of the analysis, explained variance increased by $12.3 \%$. The entire model explained a total of $25 \%$ of relationship satisfaction.

Adding relationship efficacy into the analysis lowered the size of regression coefficients which enabled us to further test our hypothesis about its mediating effect. We did two analyses in which we tested the mediational influence of relationship efficacy on the direct relationship between (1) experienced external stress and (2) perceived stress and relationship satisfaction. We controlled for common leisure time and overlap of duties in all the analyses. We used bootstrap analysis (Preacher \& Hayes, 2008) to assess the significance of indirect effects. The reliability interval that did not include zero represented a significant indirect effect with $p<.05$.

As shown in Figure 1, relationship efficacy significantly mediated the relationships between experienced external stress and relationship satisfaction (BootLLCI $=-.0177$, BootULCI $=-.066$ ). However, the mediation was only partial, since experienced external stress retained its significant direct effect (LLCI = -.0218 , ULCI $=-.0012$ ) even when relationship efficacy was controlled for. Higher levels of experienced stress lowered relationship satisfaction both directly and 
indirectly by lowering relationship efficacy which was in turn associated with less relationship satisfaction.

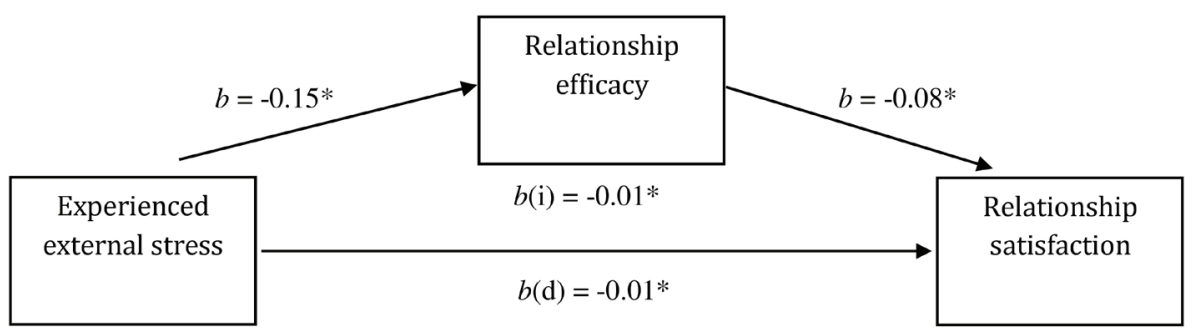

Figure 1. Results of mediational analysis - direct and indirect effects of experienced external stress on relationship satisfaction. $b(\mathrm{i})=$ indirect effect; $b(\mathrm{~d})=\mathrm{di}$ rect effect; $b=$ non-standardized regression coefficients.

$* p<.05$.

We found full mediation of relationship efficacy in the case of perceived stress and its direct and indirect effects on relationship satisfaction (see Figure 2). Indirect effect was significant (BootLLCI $=-.0306$, BootULCI $=-.0143$ ). The direct effect of perceived stress on relationship satisfaction was no longer significant after controlling for relationship efficacy (LLCI $=-.0207$, ULCI $=.0067$ ).

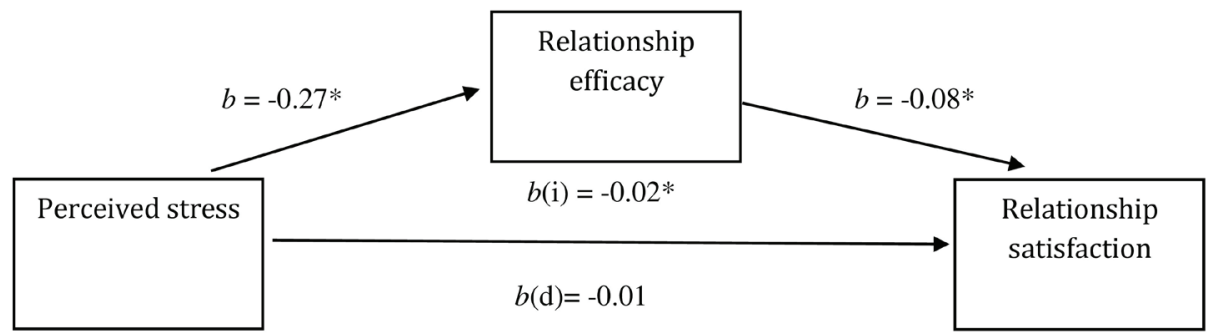

Figure 2. Results of mediational analysis - direct and indirect effects of perceived stress on relationship satisfaction. $b(\mathrm{i})=$ indirect effect; $b(\mathrm{~d})=$ direct effect; $b=$ non-standardized regression coefficients.

$* p<.05$.

\section{Discussion}

The obtained results have confirmed our hypotheses, and they are in accordance with theoretical assumptions and results from prior research of stress spillover. Both the sources of external stress and perceived stress have proved to be significant predictors of relationship satisfaction. This finding is consistent with previous studies on married couples (Buck \& Neff, 2012; Bradbury \& Karney, 
2010), and result trends from Bowlin's (2013) research on unmarried students. Although these two constructs are fairly similar, they are only moderately correlated $(r=.31)$, and they assess different aspects of stress, as previously mentioned. It seems that both the quantity of stressful events in one's life, and thoughts and feelings accompanying those events distinctly contribute to explaining relationship satisfaction.

It is important to note that the observed effects of external stress were significant while the potential influence of common leisure time and daily duties overlap was controlled for. In general, couples that spend more time apart (their daily duties do not overlap), and couples with less common leisure time report on less relationship satisfaction (Hill, 1988; Huić, Kamenov, Jelić, Mihić, \& Mihić, 2013), a finding confirmed by this study as well. It is important for future studies to control for these factors as well, since both of them represent important contextual factors for relationships.

Results also indicate that relationship efficacy can explain the association between external stress and relationship satisfaction by clarifying the way in which stress spillover occurs. Stress experienced outside the relationship takes the energy and weakens partner's capacities, which can lead to internal stress in form of more conflicts, bad communication patterns, negative attributions of partner's behavior, and similar adverse interactions (Bodenmann \& Shantinath, 2004; Neff \& Karney, 2004; Repetti, Wang, \& Saxbe, 2009). Self-regulation processes can have a buffering effect in such situations (Bodenmann \& Shantinath, 2004; Buck \& Neff, 2012; Neff, 2012). Thus it is not surprising that relationship efficacy (the feeling that we are able to successfully solve relationship problems and conflicts) helps us to cope with negative consequences of stress spillover, reducing e its negative influence on relationship satisfaction.

It is interesting to note that higher instances of external stress lowered relationship satisfaction both indirectly (by diminishing self-regulatory capacities) and directly. This illustrates the strength of the external stress spillover effect. This finding also opens up questions about other possible mediators and moderators which should be investigated in future studies. For example, it is possible that the effects of stress spillover are more adverse in individuals with insecure attachment styles than in those with secure attachment. Also, it possible that external stress makes the socio-emotional climate of the relationship unfavorable by leading to more antagonism and less expressions of affection. This unfavorable climate might lead to less relationship satisfaction in turn.

On the other hand, when experiences of stress were operationalized by the level of different stress symptoms experienced in the prior month (the so called perceived stress), we observed full mediation of relationship efficacy. In this study we used levels of perceived stress as a measure of secondary cognitive appraisal. In order to perceive higher levels of stress, individuals had to evaluate different situations as stressful. At the same time that meant they needed to evaluate their resources to deal with the same situations as poor. Since relationship efficacy can 
serve as a valuable resource for dealing with stress, it is not surprising that in this case it fully mediates the relationship between perceived stress and relationship satisfaction.

A limitation of our study lies in the fact that our participants were individuals and not couples, which meant that we analyzed the data on an individual level. Future research should focus on couples as a unit of analysis, because in the case of interpersonal research, dyadic analyses can provide more thorough and accurate information about the processes within partner relationships. Another possible limitation is the lack of information about having children. The study was intended for young, unmarried adults in dating relationships, who are not living with their partner. Therefore we assumed that participants did not have children, but we cannot be certain of that assumption. Although theoretically this might have influenced our results, having children would constitute an internal stressor in the context of our study, and not external one. Therefore we believe that it would not be a significant factor in terms of effects of external stress on relationship satisfaction. Finally, it was important to state that the research was conducted on a convenience sample. We recruited participants via social networks, forums and email, which meant that we mostly collected data from people who were available and motivated to join the study. Since the distribution of relationship satisfaction was negatively asymmetric, we can assume that more satisfied couples were more prone to take part in a study dealing with intimate relationships. Effects of external stress and relationship efficacy might be different for those less satisfied with their relationships. Also, a relatively homogenous sample reduces the possibility of generalization.

However, this study still contributes to a better understanding of stress spillover phenomena in dating relationships, which are important to be studied in order to gain a better understanding of relationships process before getting married. Our findings also enable us to better understand the exact mechanisms underlying the relationship between stress spillover and relationship outcomes. Of course, the correlational nature of the study does not allow any firm conclusions to be drawn about the causal nature of our results, and future experimental research is needed before final conclusions. Our study can also provide certain guidelines for couple education, counseling and/or therapy. According to our results, it is important for the couples to fathom the role which external stress plays, , and its potential consequences for the relationship. In addition, it is important to work on reducing the level of external stress or enhancing coping mechanisms. The findings indicate that relationship efficacy can serve as a buffering factor, if it is not undermined under the influence of stressful circumstances. Thus it would be useful to work on empowering partners' perception of their relationship efficacy. 


\section{References}

Bandura, A. (1982). Self-efficacy mechanism in human agency. American Psychologist, 37, 122-147. doi: 10.1037/0003-066X.37.2.122

Bodenmann, G., \& Cina, A. (2006). Stress and coping among stable-satisfied, stable-distressed and separated/divorced Swiss couples: A 5-year prospective longitudinal study. Journal of Divorce and Remarriage, 44, 71-89. doi: 10.1300/J087v44n01_04

Bodenmann, G., \& Shantinath, S. D. (2004). The couples coping enhancement training (CCET): A new approach to prevention of marital distress based upon stress and coping. Family Relations, 53, 477-484. doi: 10.1111/j.01976664.2004.00056.x.

Bodenmann, G. (1997). Dyadic coping - a systemic-transactional view of stress and coping among couples: Theory and empirical findings. European Review of Applied Psychology, 47, 137-140.

Bowlin, C. (2013). The interaction between relationship satisfaction and perceived stress in graduate psychology students (Unpublished master thesis). Chicago: The Chicago School of Professional Psychology.

Bradbury, T. N., \& Karney, B. R. (2010). Intimate relationships. New York: W. W. Norton \& Company.

Buck, A. A., \& Neff, L. A. (2012). Stress spillover in early marriage: The role of self-regulatory depletion. Journal of Family Psychology, 26, 698-708. doi: $10.1037 / \mathrm{a} 0029260$

Cohen, S., Kamarck, T., \& Mermelstein, R. (1983). A global measure of perceived stress. Journal of Health and Social Behavior, 24, 385-396. doi: $10.2307 / 2136404$

Fincham, F. D., Harold, G. T., \& Gano-Phillips, S. (2000). The longitudinal association between attributions and marital satisfaction: Direction of effects and role of efficacy expectations. Journal of Family Psychology, 14, 267-285. doi: 10.1037/0893-3200.14.2.267

Hill, M. S. (1988). Marital stability and spouses' shared time: A multidisciplinary hypothesis. Journal of Family Issues, 9, 427-451. doi: $10.1177 / 019251388009004001$

Huić, A., Kamenov, Ž., Jelić, M., Mihić, I., \& Mihić, V. (2013). Slobodno vrijeme i zadovoljstvo brakom u Hrvatskoj i Srbiji - rodne i generacijske razlike [Leisure time and relationship satisfaction in Croatia and Serbia - gender and age differences]. In I. Jerković \& Ž. Kamenov (Eds.), Uloge, stavovi i vrednosti: transgeneracijska perspektiva [Roles, attitudes, and values: Transgenerational perspective] (pp. 73-95). Novi Sad: Faculty of Philosophy Novi Sad.

Jerusalem, M., \& Schwarzer, R. (1992). Self-efficacy as a resource factor in stress appraisal processes. In R. Schwarzer (Ed.), Self-efficacy: Thought control of action (pp. 195-213). Washington, DC: Hemisphere. 
Lazarus, R. S., \& Folkman, S. (2004). Stres, procjena i suočavanje [Stress, assessment, and coping]. Jastrebarsko: Naklada Slap.

Lopez, F. G., Morúa, W., \& Rice, K. G. (2007). Factor structure, stability, and predictive validity of college students' relationship self-efficacy beliefs. Measurement and Evaluation in Counseling and Development, 40, 80-96.

Neff, L. A., \& Broady, E. F. (2011). Stress resilience in early marriage: Can practice make perfect? Journal of Personality and Social Psychology, 101, 1050-1067. doi: $10.1037 / \mathrm{a} 0023809$

Neff, L. A., \& Karney, B. R. (2004). How does context affect intimate relationships? Linking external stress and cognitive processes within marriage. Personality and SocialPsychology Bulletin,30,134-148. doi: 10.1177/0146167203255984

Neff, L. A., \& Karney, B. R. (2009). Stress and reactivity to daily relationship experiences: How stress hinders adaptive processes in marriage. Journal of Personality and Social Psychology, 97, 435-450. doi: 10.1037/a0015663

Neff, L. A. (2012). Putting marriage in its context: The influence of external stress on early marital development. In L. Campbell \& T. J. Loving (Ur.), Interdisciplinary research on close relationships: The case for integration (pp. 179-203). Washington: American Psychological Association.

Preacher, K. J., \& Hayes, A. F. (2008). Asymptotic and resampling strategies for assessing and comparing indirect effects in multiple mediator models. Behavior Research Methods, 40, 879-891. doi: 10.3758/BRM.40.3.879

Randall, A. K., \& Bodenmann, G. (2009). The role of stress on close relationships and marital satisfaction. Clinical Psychology Review, 29, 105-115. doi: 10.1016/j.cpr.2008.10.004

Repetti, R., Wang, S., \& Saxbe, D. (2009). Bringing it all back home: How outside stressors shape families' everyday lives. Current Directions in Psychological Science, 18, 106-111. doi: 10.1111/j.1467-8721.2009.01618.x

Repetti, R. L. (1989). Effects of daily workload on subsequent behavior during marital interaction: The roles of social withdrawal and spouse support. Journal of Personality and Social Psychology, 57, 651-659. doi: 10.1037/00223514.57.4.651

Shurts, W. M., \& Myers, J. E. (2012). Relationships among young adults' marital messages received, marital attitudes, and relationship self-efficacy. Adultspan Journal, 11, 97-111. doi: 10.1002/j.2161-0029.2012.00009.x

Sullivan, T. P., McPartland, T., Price, C., Cruza-Guet, M. C., \& Swan, S. C. (2013). Relationship self-efficacy protects against mental health problems among women in bidirectionally aggressive intimate relationships with men. Journal of Counseling Psychology, 60, 641-647. doi: 10.1037/a0033406

Tadinac, M., Kamenov, Ž., Jelić, M., \& Hromatko, I. (2005). Što ljubavnu vezu čini uspješnom? [What makes an intimate relationship succesfful?] Izvještaj $s$ XV. Ljetne psihologijske škole [XV. Psychology School Research Report](pp. 1112). Zagreb: Department of Psychology, Faculty of Humanities and Social Sciences. 


\section{Ivana Bahun}

Psihijatrijska bolnica

"Sveti Ivan", Zagreb

\section{Aleksandra Huić}

Odsjek za psihologiju, Filozofski fakultet, Sveučilište u Zagrebu
INTIMNE VEZE U KONTEKSTU: ODNOS VANJSKOG STRESA, SAMOEFIKASNOSTI U INTIMNOM ODNOSU I ZADOVOLJSTVA VEZOM

U novije vrijeme istraživanja su pokazala da je stres doživljen izvan partnerskog odnosa negativno povezan s procenama različitih ishoda intimne veze, kao što je zadovoljstvo vezom. Međutim, točni mehanizmi putem kojih ovaj fenomen, poznat pod nazivom stress spillover ili prelevanje stresa, ostvaruje svoj uticaj nisu u potpunosti razjašnjeni. Osim toga, većina istraživanja sprovedena je na bračnim parovima, dok se manje zna o njegovim efektima unutar hodanja. Cilj ovog istraživanja bio je ispitati odnos između vanjskog stresa, percepcije samoefikasnosti u intimnom odnosu i zadovoljstva vezom na prelasku u odraslu dob. U istraživanju je sudelovalo ukupno 390 osoba u dobi između 18 i 35 godina, koje su u vezi duljoj od šest mjeseci, a ne žive s partnerom. Ispitani su izvori vanjskog stresa, stupanj percipiranog stresa, doživljaj samoefikasnosti u intimnom odnosu, zadovoljstvo vezom i neke karakteristike veze. Rezultati su pokazali da je stres doživljen izvan partnerskog odnosa negativno povezan sa zadovoljstvom vezom. I izraženost izvora vanjskog stresa i percipirani stres značajno pridonose objašnjavanju zadovoljstva vezom. Rezultati upućuju na posredujući učinak osjećaja samoefikasnosti u intimnom odnosu na povezanost između izvora vanjskog stresa i percipiranog stresa te zadovoljstva vezom. Što je više izvora vanjskog stresa i percipiranog stresa, to je procena samoefikasnosti u intimnom odnosu manja, a manja samoefikasnost povezana je s manjim zadovoljstvom vezom. Nalazi ukazuju na važnost samoregulacije za procese koji se odvijaju unutar intimnih odnosa na prelasku odraslu dob. Čini se kako niža samoefikasnost u intimnom odnosu pomaže objasniti negativne učinke prelevanja vanjskog stresa u partnerski odnos.

Ključne riječi: partnerski odnosi, kontekst, prelijevanje stresa, samoefikasnost u intimnom odnosu, zadovoljstvo vezom 